\title{
NATURAL APPROACH IN ENGLISH CLASSES IN PRIMARY SCHOOLS: TEACHERS' PERCEPTIONS AND IMPLEMENTATION
}

\author{
I.G.E.P. Giri' ${ }^{1}$ L. P. Artini, ${ }^{1}$, N. N. Padmadewi² \\ ${ }^{123}$ English Language Education, Post Graduate Program, Universitas Pendidikan Ganesha, Singaraja \\ e-mail: pranatagiri.gmail.com, putu.artini@undiksha.ac.id, nym.padmadewi@undiksha.ac.id
}

This study aimed at investigating teachers' perceptions about natural approach in teaching English for young learners and its implementation in public primary schools in Gianyar Regency, particularly on teachers' perceptions on natural approach in teaching English for young learners, how the English teachers implement naturalistic values in teaching English as a foreign language in Gianyar regency, and teachers' perceptions about naturalistic values for young learners related to the strategies in teaching English as a foreign language in classroom. The subjects of the study were 3 English teachers in 3 different public elementary schools in Gianyar Regency. The research design of the study was mixed methods. This study used three instruments: observation sheets, questionnaires, and interviews. The observation sheet was used to find out how teachers implemented the naturalistic values in teaching English for young learners. The questionnaire was used to find out teachers' perceptions on natural approach and the interview was used to find out how teachers' perceptions related to their strategies in teaching English for young learners in their classrooms. This study showed that the relation between teachers' perceptions and the implementation found that there were few results indicated inconsistency between both of them. The data were also supported by the result of interviews.

Keywords: naturalistic values, teachers' perception, teaching English for young learners, and Public Primary Schools.

\section{INTRODUCTION}

In Indonesia, primary schools with English only or bilingual approaches have increasingly established and gained popularity among parents and children. The presence of English subject in primary schools in Indonesia is intended to make children able to understand the English language at their early ages, not only in big cities but also in small cities as in Gianyar Regency. According to Artini (2016), English as an optional subject in primary school has been a part of the local content curriculum since 1994. It means the English subject can be given or not in the schools depending upon the schools' policy or government's policy. For example, as in Gianyar Regency, English is included as a local subject in the primary schools due to the fact that Gianyar is popular with the tourism object. So, the government in Gianyar Regency wants to introduce foreign language especially English to primary students since an early age. Teaching English since an early age is beneficial and more effective since children' brain is easy to absorb a new language. The mastery of English is also perceived to be a valuable investment for young learners' future. In Gianyar, English as a local content subject is taught to the fourth, fifth and sixth grade students.

Primary school students belong to young learners if it is seen from the age of the children. Teaching English to young learners is different from teaching English to adolescence or adult learners because young learners are more enthusiastic in the classrooms. In learning a new language, young learners have no awareness of grammatical mistakes and are less embarrassed to talk and they also tend to speak like natives due to their lack of inhibition (Cameron, 2001).

In line with that, teaching young learners have a distinct impression for the teachers, like Schneiderova (2013) who has stated that teaching young learners can be challenging, rewarding and even surprising. Harmer (2007) claims that young learners have different characteristics and they learn differently from adolescents, adults, and even from older children. The teachers also should consider that young learners have a low concentration span 
and short memory (Yang. 2001). Children take good pleasure in finding and creating fun in what they do. Children have a ready imagination, children's words are full of imagination and fantasy, and it is more than simply a matter of enjoyment.

Teachers who deal with young learners must have competence both professional competence and pedagogical competence. Working with young learners gives opportunities for language teachers to develop what the learners have already had. They, young learners, do not come to the class of language empty-handed, they have already had well-established instincts, skills, and characteristics which help them to learn another language (Halliwell, 1992). Due to the situation, teachers need to use appropriate classroom strategy, method and approach in teaching and learning process especially to teach young learners. In a great sense, it can be said that good and suitable teachers' classroom strategy, method and approach for young learners' English class can make the aim of the learning process be accomplished succesfully.

Throughout the last several decades, a general concern has risen among early childhood teachers concerning the policies and content of early primary education programs. This new concern is highly related to the capabilities of young learners in primary school education areas.

To educate 21st century young learners, a teacher is demanded to have balanced knowledge in both theory and practice. Focusing on teaching English for young learners, regardless of whether English is taught as a compulsory or local subject, primary school students need introductory concepts of English covering several skills and components. To encourage the students' English mastery, the teacher indeed becomes the center point of the class. The success in achieving the competencies depends on how creative and innovative the instructors are.

In order to make students learn effectively and efficiently, a teacher has to perform a large number of activities inside and outside the classroom. The teacher is expected to possess a certain amount of knowledge, certain attitudes, and skills, which is known as teachers' competence. In other words, teachers' competence included the right way of conveying units of knowledge, application, and skills to students (Richard, 2011). High teacher's competence is so crucial that it can beneficially lead to positive individual student development, and it even would lessen the aggressive behavior in the classroom.

In line with the teacher's competency, the teacher's role is very important in supporting the learning process for young learners. The teacher must be able to create an interesting learning and can be understood by students. The activity of students in learning is one of the factors that influence of the students' success in a lesson. Students are expected to be truly active in learning, so it will have an impact on students' memories of the subject matter. For young learners, to be able to understand the English language needs a special way, a way that is interesting, easy, and applicable for their ages. To achieve goals, there must be some components as the supporting components of learning provided by the teachers. A suitable teaching approach is applied to young learners brings the teachers to success, gets their objectives of learning. The teachers also have to choose an appropriate approach in teaching young learners.

There are some approaches in teaching English for young learners, such as: humanistic approach, behavioristic approach, constructivists approach, and naturalism approach. All of the approaches have their own strengths and weaknesses. There are no better or worse approaches, the use of approaches depends on the learners' need and learning situation in the classroom.

There is one approach that is applicable for teaching young learners, which is natural approach. Natural approach is a language teaching approach, which claims that as a native language is acquired by the students, target language should also be learned in a natural way (Krashen and Terrell, 1983). This approach focuses on giving less emphasis on teacher talking for a long time, making students repeat what the teachers' say, and limiting the questions to the textbook alone, and more importantly, less focus on accuracy in terms of target language sentences. The natural approach is derived from naturalism, which means belief in Nature. This philosophy believes that "everything comes from nature and returns to nature". 
Here, the term of naturalistic values in implementing the teaching and learning process in the classroom. The naturalistic values give less emphasis on teacher talking for a long time, making students repeat what the teachers' say, and limiting the questions to the textbook alone, and more importantly, less focusing on accuracy in terms of target language sentences (Richards and Rodgers, 1986). In the naturalistic values, the teacher uses the target language to communicate in the classroom, whereas students can use either the language being taught or their mother tongue. Moreover, the teacher creates a classroom atmosphere that is interesting, friendly, and there is a low affective filter for learning. This is achieved in part through such naturalistic values as not demanding speech from the students before they are ready for it, not correcting students' errors, and providing the subject matter of high interest to students.

In implementing this approach, sometimes the English teachers of public primary schools in Gianyar Regency were not aware that they used this kind of approach in the classroom. It is important to know English teachers' perceptions of naturalistic values in teaching English for young learners in the classroom. The English teachers may have a different perspectives about naturalistic values and how it is implemented in teaching English for young learners. Therefore, this study attempted to investigate teachers' perceptions about naturalistic values in teaching English for young learners and its implementation in public primary schools in Gianyar Regency.

\section{RESEARCH METHOD}

Research Design is a mixed methods design approach that was used to investigate the implementation of conceptual knowledge and pedagogical practices of English primary school teachers in Gianyar municipality on child centered learning in teaching English for young leamers. In this study, the data were collected through observation sheet, questionnaire form, and interview. The questionnaire was developed by using open-ended questions. It is used to answer the research question number one. The observation sheet was used to answer the research question two. Meanwhile, the interview was used an interview guide in collecting the data to answer research question number three.

In this study, the data were collected through observation sheet, questionnaire form, and interview. The questionnaire was developed by using open-ended questions. It is used to answer the research question number one. The observation sheet was used to answer the research question two. Meanwhile, the interview was used an interview guide in collecting the data to answer research question number three.

The observation sheet was given to three English teachers from different public primary school in Gianyar Regency. The observation sheets used to find out teachers' perceptions of Naturalism values in teaching English for young learners in public primary schools. The researcher did not join any class participation during observing the teachers in order to get the natural data. The researcher observed every teacher for three times or three meetings. Here the observation sheet table that given to the teachers.

In this study, the researcher used interview guide in gathering the data. The interview guide was used to find out about teachers' perceptions and the implementation of naturalism values in teaching English for young learners. This instrument supported the information of the questionnaire in giving more information about the perspective of English teachers in applying naturalism values in the classroom. The questions of the interview was developed from the results of the questionnaires of three English teachers. The interview was developed based on several different questions which they answered orally. The researcher wrote their answers instantly so that the researcher could copy exactly what they were saying.

This study used questionnaire to collect data from three English teachers in public primary schools in Gianyar Regency. The questionnaire used five-point likert scale items. There were 35 statements in the questionnaire. The purpose of this questionnaire was to gather information of teachers' perceptions of naturalism values in teaching English for young learners. The teacher answered the questionnaire after the observation was done. The questionnaires were completed and collected on the spot. The results of the questionnaire on 
Naturalism values in teaching English for young learners were used to know the perceptions of English teachers in public primary schools in Gianyar Regency. It used the guideline of qualification level proposed by Koyan (2012).

\section{FINDINGS AND DISCUSSION}

This research conducted in three different primary schools in Gianyar Regency. The schools are SD N 1 Celuk, SD N 2 Celuk and SD N 3 Batubulan. All of the schools are public primary schools that use the similar curriculum in teaching the students. They use K13 as their curriculums. In every primary school in Gianyar Regency, There is only one English teacher to teach English subject.

Based on the teachers' profile above, it can be seen that the English teachers have some differences in terms of gender, length of service, educational background, and additional education. Therefore, the teachers' perceptions on naturalistic values in teaching English for young learners can be different one to another.

This study was about investigating teachers' perception in TEYL on naturalistic value in public primary school in Gianyar Regency. There were three research objectives in this study, such as: 1) to find out the perception of the English teacher in public primary school in Gianyar on naturalistic value in teaching English for young learners, 2). to find out the way English teachers implement naturalistic value in teaching English as a foreign language in Gianyar Regency, and 3). to find out teachers' perception about naturalistic value for young learners related to the strategies in teaching English as foreign language in classroom. The subjects of this study were three English teachers in three different public primary schools in Gianyar Regency. Those primary schools were SD No. 1 Celuk, SD No. 2 Celuk, and SD No. 3 Batubulan. The participants consisted of two male English teachers and one female English teacher. In choosing the participants, the researcher used purposive sampling. It had one condition which was the participants should be English teachers in public primary schools in Gianyar Regency. This research used mixed method in analysing the data. The type of mixed method used in this study was an embedded design analysis proposed by Creswell (2012). This study used three instruments in collecting the data through observation sheet, questionnaire form, and interview. The questionnaire was used to know the teachers' perceptions of naturalistic value. The observation was used to know the implementation of naturalistic value. The last was an interview, it was used to know the relation between the concept and the implementation of naturalistic value in public primary schools in Gianyar Regency.

The first research question of this study was to find out the perceptions of the English teacher in public primary school in Gianyar on naturalistic values in teaching English for young learners. Teachers' perceptions questionnaire on naturalistic values in teaching English for young learners. Based on the result of teachers' perceptions questionnaires of three English teachers on naturalistic values, it found that the majority of the participants had very strong perceptions on naturalistic values.

The second research question of this study was the activity that mostly appeared was in the component learner as a listener and performer, teachers are primary source of comprehensible input, start with TPR commands, and teachers create an interesting classroom atmosphere. English teachers strongly agreed that the activities of using TPR were very commonly used in teaching English in Elementary schools. They believed TPR as a part of naturalistic values still applicable used in teaching young learners. That result was in line with the statements proposed by Krashen and Terrell (1983), the naturalistic values "is for beginners and is designed to help them become intermediates." It has the expectation that students will be able to function adequately in the target situation.

The third research question of this study was the relation of the teachers' perceptions about naturalistic values for young learners with the strategies in teaching English as a foreign language in the classroom. In the finding, it found that Inconsistency between the perceptions and the implementations happen in the component that states Use TPR to teach the materials, since the perception is very strong while the implementation is low. It also happens in the concept of Introduce classroom terms and props into commands, Use picture, visuals aids and 
realia with commands and conditionals in introducing new vocabulary, Teachers chose a rich mix of classroom activities. Teachers' perceptions about those concepts are very strong and strong, meanwhile the implementation is very low and low. Those components showed the gap between the teachers' perceptions and the implementation on naturalistic values in teaching English for young learners. It can be seen through the result that teachers' perceptions were very strong and the implementation was low. It can be assumed that sometimes teachers did not realize, they did not implement what they already knew in their mind. In order to find the reasons of those inconsistencies between the perception and the implementation, the researcher followed up by interviewing the participants.

In short, the findings and discussion of this study showed teachers' perceptions and the implementation sometimes inconsistency in few parts. Overall all of the results showed those teachers' perceptions had very strong perceptions of naturalistic values. In term of the implementation, the result showed some of the learning activities almost appeared in all indicators, meanwhile only several activities were not frequent appeared in the indicators. Thus, the relation between teachers' perceptions and the implementation found that there were few results that showed inconsistency between both of them. The data were also supported by the result of the interviews.

\section{CONCLUSION AND SUGGESTIONS}

The teachers' perceptions reached a very high category or belong to a very strong perception of naturalistic values based on the total qualification 1evel proposed by Koyan (2012). It can be seen the lowest number of perception was 3.0 and the highest number of perception was 4.6. In addition, it can be assumed that the three teachers were still used naturalistic values in the learning process, that was why they answered the question bravely by giving 5 or 4 , and only a few gave 3 for the statements of the questionnaires.

According to the result of the relation between perceptions and implementation, it is found that the category of the relation of the first component which is Learner as a listener and performer is consistent. The second component which is Learn to identify things based on the materials is categorized into slight consistent. The relation between teachers' perceptions and the implementation of the component Teachers are primary source of comprehensible input is categorized into consistent. Inconsistency between the perceptions and the implementations happen in the component that states Use TPR to teach the materials, since the perception is very strong while the implementation is low. It also happens in the concept of Introduce classroom terms and props into commands, Use picture, visuals aids and realia with commands and conditionals in introducing new vocabulary, Teachers chose a rich mix of classroom activities. Teachers' perceptions about those concepts are very strong and strong, meanwhile the implementation is very low and low.

The relation between teachers' perceptions and implementation showed that the relation of the first component which is learner as a listener and performer is consistent. The second component which is Learn to identify things based on the materials is categorized into slight consistent. The relation between teachers' perceptions and the implementation of the component Teachers are primary source of comprehensible input is categorized into consistent. Inconsistency between the perceptions and the implementations happen in the component that states Use TPR to teach the materials, since the perception is very strong while the implementation is low. It also happens in the concept of Introduce classroom terms and props into commands, Use picture, visuals aids and realia with commands and conditionals in introducing new vocabulary, Teachers chose a rich mix of classroom activities. Teachers' perceptions about those concepts are very strong and strong, meanwhile the implementation is very low and low.

In relation to the findings found in this study, the researcher proposes some suggestions.

For police makers, the research would be beneficial for the teachers' professional development through supporting the development of significant teachers' professional activities. For English Young Learners teachers can participate in some seminars or workshops to fulfill their knowledge in teaching English for young learners. 
For further studies, researchers can conduct studies on the same topic about investigating teachers' perception in TEYL on naturalistic value in public primary school in Gianyar Regency. The findings of this study could also be beneficial for them as their references in developing similar study because only a few researches conducted this topic. Therefore, they can conduct better research in the future. Observation and interviews are recommended to get more data. Observations can be used to analyses how teachers implement naturalistic value in teaching English in the classroom, and through interview, researchers can know the reasons why the teacher used those approach in the classroom. Therefore, the researcher will get rich data for the study.

\section{REFERENCES}

Artini, L. P (2017). Rich Language Learning Environment and Young Learners Literacy Skills in English. Indonesia: Lingua Cultura.

Asher, J. (1982). The Total Physical Response Method for Second Language Learning. California. San Jose State Collage.

Cameron, L. (2001). Teaching Languages to Young Learners. Cambridge: Cambridge University Press.

Chan Y.C. (2008). Elementary school EFL teachers' beliefs and practices of multiple assessments. National Taipei University of Education.

Copland, F., Garton, S., and Burns. A. (2014). Challenges in teaching English to Young Learners: Global perspectives and local realities. England: Aston University.

Creswell, J.W. (2012). Educational Research (4th ed.). New York Pearson Education Inc.

Dick, W. and Carey L. (1990). The Systematic Design of Instruction. Florida Stated University.

Dochy, F. J., \& Alexander, P. A. (1995). Mapping prior knowledge: A framework for discussion among researchers. European Journal of Psychology of Education.

Furberg, E. (2010). How do students' perceptions of their education change over time. Umea University.

Halliwell, S. (1992) Teaching English in the Primary Classroom. Harlow: Longman.

Handayani, S. (2014). The Implementation of Montessori Method for the Teaching of English Language at Singapore Piaget Academy International School Solo Baru. Universitas Muhammadiyah Surakarta.

Harmer, J. (2001). How to Teach English. An Introduction to the Practice of English Language Teaching. England: Longman.

Harmer, J. (2007). The practice of English language teaching (4th ed.). Harlow: Longman.

Herrell. A and Michael Jordan. (2015). 50 Strategies for Teaching English Language Learners (5th Edition). Boston, MA Pearson.

Horwitz, E. K. (1987). Surveying student beliefs about language learning. In A. L. Wenden \& J. Rubin (Eds.). Learner strategies in language learning, (pp.119-129), Englewood Cliffs, New Jersey: Prentice Hall.

Huyen, N., \& Nga, K. (2003). Learning Vocabulary through Games. Asian EFL Journal.

Koyan, I. W. (2012). Statistik pendidikan teknik analisis data kualitatif. Singaraja: Undiksha Press.

Krashen, S.D. \& Terrell, T.D. (1983). The natural approach: Language acquisition in the classroom. London: Prentice Hall Europe.

Krashen, S.D. \& Terrell, T.D. (1983). The natural approach: Language acquisition in the classroom. London: Prentice Hall Europe. 
Linse, C.T. and Nunan, D. (2005).Practical English Language Teaching: Young Learners. McGraw-Hill ESL/ELT, New York.

Moedjito. (2016). The Teaching of English Pronunciation: Perceptions of Indonesian School Teachers and University Students. STKIP Hamzanwadi Selong.

Pinter A. (2016) Secondary ELT : issues and trends. In: Hall, Graham, (ed.) The Routledge Handbook of English Language Teaching. London: Routledge.

Pinter A. (2006). Teaching Young Language Learners. Oxford: Oxford University Press.

Quick, D.L. and Nelson, J.C. (1997), Organizational Behavior: Foundations, Realities, and Challenges, (New York: West Publishing Company).

Rao, V. S. P. And Narayana, P. S. (1998), Organization Theory and Behaviour. Delhi: Konark Publishing Company.

Richard, J. C. and Theodore S. Rodger. (1986). Approaches and Methods in Language Teaching. London: Cambridge University Press.

Richard, J. C and Theodore S. Rodger. (1999). Approaches and Methods in Language Teaching. London: Cambridge University Press.

Richards, J. C. (2001).Competence and performance in language teaching. New York, NY: Cambridge University Press.

Sam, P. (2016). Natural Approach of Teaching English Language on a Flipped Classroom Platform to Tertiary Level Engineering Learners.

Schneiderova, P. (2013). The effective classroom management in young learners' language classes. Faculty of Education: Masaryk University,Brno.

Shinde, M. B., \& Karekatti, T. K. (2012). Pre-service teachers' beliefs about teaching English to primary school YLs. International Journal of Instruction.

Subasi \& Kara (2010). Teachers' beliefs on foreign language teaching practices in early phases of primary education: a case study. Turkey: Anadolu University.

Subhan, Z. (2017). The pedagogy of teaching English to young learners: Implications for teacher education. Australia: The University of Queensland.

Yang, M. (2001). Seven tips for teaching young learners English. Teaching English in china, 24(4). Retrieved January 7, 2016 from: http://www.asian-efl-journal.com/Thesis/ThesisWang.pdf 